\title{
Fatty Acid Derivatives of Clozapine: Prolonged Antidopaminergic Activity of Docosahexaenoylclozapine in the Rat
}

\author{
Ross J. Baldessarini, M.D., Alexander Campbell, M.Phil., Nigel L. Webb, Ph.D., \\ Charles S. Swindell, Ph.D., James G. Flood, Ph.D., Victor E. Shashoua, Ph.D., \\ Nora S. Kula, M.S., S. Hemamalini, Ph.D., and Matthews O. Bradley, Ph.D.
}

Stable amides of clozapine derived from fatty acids prominent in cerebral tissue might enhance the central activity of clozapine and reduce its exposure to peripheral tissues. Such derivatives might enhance the safety of this unique drug, which is the only agent with securely established superior antipsychotic effectiveness, but with a risk of potentially lethal systemic toxicity. Amide derivatives of clozapine were prepared from structurally varied fatty acid chlorides and evaluated for ability to inhibit behavioral arousal in rat induced by dopamine agonist apomorphine and to induce catalepsy. Their duration-of-action and potency were compared to free clozapine, and concentrations of clozapine were assayed in brain and blood. Selected agents were also evaluated for affinity at dopamine receptors and other potential drug-target sites. Clozapine-N-amides of linoleic, myristic, oleic, and palmitic acids had moderate initial central depressant activity but by $6 \mathrm{~h}$, failed to inhibit arousal induced by apomorphine. However, the docosahexaenoic acid (DHA) derivative was orally bioavailable, 10-times more potent $\left(E D_{50} 5.0 \mu \mathrm{mol} / \mathrm{kg}\right)$ than

From the Consolidated Department of Psychiatry and Neuroscience Program (RJB, AC, VES, NSK) and Department of Pathology (JGF), Harvard Medical School, Boston, MA; Mailman Research Center, McLean Division of Massachusetts General Hospital, Belmont, MA (RJB, AC, VES, NSK); Protarga, Inc., Conshohocken, PA (NLW, CSS, SH, MOB); and Clinical Chemistry Laboratory, Massachusetts General Hospital, Boston, MA (JGF).

Address correspondence to: Ross J. Baldessarini, M.D., Neuropharmacology Laboratory, Mailman Research Center, McLean Hospital, 115 Mill Street, Belmont, MA 02478.

Received 28 February 2000; revised 2 June 2000; accepted 30 June 2000. clozapine itself, and very long-acting ( $\geq 24 \mathrm{~h}$ ) against apomorphine, and did not induce catalepsy. DHA itself was inactive behaviorally. Clozapine showed expected dopamine receptor affinities, but DHA-clozapine was inactive at these and other potential target sites. After systemic administration of DHA-clozapine, serum levels of free clozapine were very low, and brain concentrations somewhat lower than after administering clozapine. DHA-clozapine is a long-acting central depressant with powerful and prolonged antidopaminergic activity after oral administration or injection without inducing catalepsy, and it markedly reduced peripheral exposure to free clozapine. It lacked the receptor-affinities shown by clozapine, suggesting that DHA-clozapine may be a precursor of free, pharmacologically active clozapine. Such agents may represent potential antipsychotic drugs with improved central/peripheral distribution, and possibly enhanced safety.

[Neuropsychopharmacology 24:55-65, 2001] (c) 2000 American College of Neuropsychopharmacology. Published by Elsevier Science Inc.
KEY WORDS: Blood-brain barrier; Clozapine;

Docosahexaenoic acid; Dopamine; Fatty acids; Linoleic acid; Myristic acid; Oleic acid; Palmitic acid

Clozapine is a virtually unique antipsychotic agent in having shown superior effectiveness in a series of randomized comparisons with standard neuroleptics, including for treatment of otherwise treatment-resistant psychotic patients (Kane et al. 1988; Baldessarini and Frankenburg 1991; Lieberman et al. 1994; Bondolfi et al. 1998; Wahlbeck et al. 1999). Clozapine is also one of the 
rare psychiatric treatments found to limit suicidal risk (Meltzer 1998; Baldessarini and Jamison 1999). However, its clinical utility is limited by adverse effects that include hypotension and later weight-gain and newonset insulin-resistant diabetes II, the pathophysiology of which remains incompletely defined, as well as dosedependent risk of centrally mediated adverse effects, including excessive sedation and epileptic seizures (Baldessarini and Frankenburg 1991; Hägg et al. 1998). Moreover, clozapine is associated with severe bone marrow toxicity, including agranulocytosis that may not be dose-dependent and is hard to predict except by close monitoring of circulating leukocyte counts (Gerlach 1991; Alvir et al. 1993).

Given the unusual benefits and substantial risks of clozapine, we considered that it may be feasible to increase the ratio of utility to risk of adverse effects of this important drug by modifying its access to brain target sites. As a strategy aimed at testing this hypothesis, we followed our previous findings with ester or amide derivatives of fatty acids important in the composition of brain tissue, including some that are effectively transported into the central nervous system (CNS). Such derivatives can markedly enhance entry of some compounds into the brain, including hydrophilic agents such as GABA and dopamine (Jacob et al. 1985; Shashoua and Hesse 1996). Accordingly, we considered preparing derivatives of clozapine and fatty acids that are abundant in brain tissue but must be supplied exogenously and transported through the blood-brain barrier. We hypothesized that such compounds might increase and prolong the uptake of clozapine into the brain, with an enhanced ratio of brain/blood concentrations of clozapine over time, or be neuropsychopharmacologically active in their own right. Such derivatives might yield more clinically favorable risk/benefit relationships (therapeutic index) than are provided by free clozapine itself.

Docosahexaenoic acid (DHA) is a particularly interesting candidate for attachment to clozapine because it is vigorously transported into the CNS and accounts for a high proportion of cerebral fatty acid content (Söderberg et al. 1991; Martin et al. 1994). Moreover, in earlier work, DHA proved particularly effective in facilitating entry of hydrophilic compounds into the brain (Shashoua and Hesse 1996).

DHA is a 22-carbon chain, omega-3, unsaturated, fatty acid containing six cis-double bonds. It is present in neuronal tissue, nerve terminals and synapses, predominantly within membrane phospholipid constituents phosphatidylethanolamine, phosphatidylserine, and phosphatidylcholine (Martin and Bazan 1992; Martin et al. 1994). Of the total fatty acid content in brain regions, DHA constitutes approximately $22 \%$ in frontal cerebral cortical gray matter, $16 \%$ in hippocampus, and in lower proportions in white matter and in some sub- cortical regions (Söderberg et al. 1991). Brain is virtually entirely dependent on intake of exogenous, and mainly dietary, DHA (Innis 1991). It and other fatty acids are transported into the CNS by incompletely defined mechanisms that may include receptor-mediation (Bazan et al. 1985; Scott and Bazan 1989; Bazan 1990; Martin et al. 1994).

Based on the preceding considerations, we prepared amide derivatives of clozapine from the acid chlorides of a series of fatty acids of varying chain-length and saturation, and tested them for potency and duration of action in inhibiting behavioral arousal in the rat induced by the centrally-acting direct dopamine receptor agonist $\mathrm{R}(-)$-apomorphine, as well as for simultaneous presence of free clozapine in serum and brain tissue.

\section{METHODS}

\section{Materials}

Fatty acids used included DHA (obtained by saponification of DHA ethyl ester from Shiseido Corporation, Tokyo, Japan) as well as linoleic, myristic, oleic, and palmitic acids (from Aldrich Chemicals, Milwaukee, WI). The corresponding acid chlorides were prepared at Protarga, Inc. by reacting the fatty acids in methylene chloride $\left(\mathrm{CH}_{2} \mathrm{Cl}_{2}\right)$ with oxalyl chloride $\left([\mathrm{COCl}]_{2}\right.$, with $\mathrm{DHA})$ or thionyl chloride $\left(\mathrm{SOCl}_{2}\right.$, with all others) at room temperature. The resulting fatty acid chlorides were then reacted with clozapine (generously provided by Novartis Laboratories, Basel, Switzerland) in the presence of pyridine in dry toluene under argon for 60 min at $120^{\circ} \mathrm{C}$.

Resulting crude reaction mixtures were purified by flash chromatography on silica gel (Merck grade 9385, 230-400 mesh, $6.0 \mathrm{~nm}$ ) with ethyl acetate:methanol (90:10, vol) as the mobile phase. The desired clozapine5 -N-amide products were obtained as viscous oils in yields of $85-95 \%$. Each novel fatty acid amide derivative of clozapine was characterized by ${ }^{1} \mathrm{H}$ NMR $(300 \mathrm{MHz}$, $\left.\mathrm{CDCl}_{3}\right)$ and ${ }^{13} \mathrm{C} \mathrm{NMR}\left(75 \mathrm{MHz}, \mathrm{CDCl}_{3}\right)$ spectroscopy. All other chemical and drug materials used were obtained from Sigma Corporation (St. Louis, MO) or its Research Biochemicals International (RBI) division (Natick, MA).

\section{Animal Subjects}

All procedures involving laboratory animals were reviewed and approved by the Institutional Animal Care and Use Committee (IACUC) of McLean Hospital, and followed pertinent federal and local regulatory guidelines. Young adult, male albino SD rats (200-300 g body $w t)$ were obtained from Charles River Laboratories (Wilmington, MA). Before experimentation, animals were allowed one week to adapt to the laboratory environment, housed under controlled lighting (lights on: 
07:00-19:00 h), temperature, and humidity, with free access to tap-water and standard Purina laboratory rat chow. They were tested in groups of $6 /$ condition following injections at a standard test vol of $1 \mathrm{ml} / \mathrm{kg}$, intraperitoneally (i.p.) or by orgogastric intubation (p.o.).

\section{Behavioral Procedures}

Rats were tested singly in their home cages between 10:00 and 16:00 $\mathrm{h}$ to minimize effects of circadian variations in behavioral responses. Locomotion was monitored as an index of behavioral arousal, either as spontaneous behavior or as stimulated by the direct central dopamine mixed $\mathrm{D}_{2}$ and $\mathrm{D}_{1}$ agonist $\mathrm{R}(-)$-apomorphine$\mathrm{HCl}$ (RBI). Locomotion was recorded in a 12-channel electronic activity monitor (Stoelting Co., Wood Dale, IL) controlled by a microcomputer, as detailed previously (Campbell et al. 1989, 1990, 1993, 1997). For experiments involving repeated testing after administration of a novel test compound, subjects included randomly constituted samples of rats tested only once or up to three times with a minimum of $24 \mathrm{~h}$ between testing sessions. Locomotor activity data were accumulated and recorded every 5 min over $60 \mathrm{~min}$, using MacLab System software (ADInstruments, Castle Hill, NSW, Australia) for the Macintosh microcomputer.

Additional behavioral assessments scored for catalepsy, using methods detailed previously (Campbell et al. 1988). Rats were placed on $45^{\circ}$ inclined grids every $10 \mathrm{~min}$ for an hour after injections of test agents, and scored for time remaining immobile up to $60 \mathrm{sec} / \mathrm{obser}-$ vation, for a maximum score of $360 \mathrm{sec}$.

All data were then transferred for analysis with Statview-5 biostatistical programs (SAS Research Inc., Cary, NC). Standard analysis-of-variance (ANOVA) methods were used to test for overall effects, followed by Scheffé post-hoc tests of planned comparisons. Differences yielding 2-tailed $p<.05$ were considered statistically significant. Data are presented as means \pm SEM unless stated otherwise.

\section{Solvent Vehicle}

Owing to the need to dissolve the large, highly lipophilic novel compounds for testing, preliminary assessments compared their solubility in various vehicles, and tested for effects of the vehicles on behavioral responses in the rat. The solvent system eventually adopted contained $\alpha$-tocopherol (70 $\mathrm{mg}$ ) and ascorbic acid (50 mg) as antioxidants, with dilaurylthiopropionic acid $(5 \mathrm{mg}$ ) in each $100 \mathrm{ml}$ of propyleneglycol. This vehicle mixture was compared with dimethylsulfoxide (DMSO, 100\% and 50\% in water), and with ethanol (50\% and $30 \%$ in water). The solvent vehicles all dissolved the test agents, but some limited locomotor behavioral arousal produced by apomorphine.
Compared to saline control injections of physiological saline before apomorphine, pure DMSO reduced behavioral arousal by $51 \%$; diluted DMSO inhibited by $17 \%$, and ethanol reduced motor activity by $25-30 \%$ at both concentrations. However, the propyleneglycol mixture did not interfere significantly with either spontaneous motor activity or with arousal induced by apomorphine, and so was adopted as the standard vehicle for subsequent experiments.

\section{Radioaffinity Assays}

DHA-clozapine, as well as free DHA and clozapine were evaluated for their interactions with several types of dopamine receptors: $\mathrm{D}_{1}$ (assayed in competition with $\mathrm{C}=300 \mathrm{pM}\left[{ }^{3} \mathrm{H}\right] \mathrm{SCH}-23390$ with cell membrane-containing homogenates of rat corpus striatum for $30 \mathrm{~min}$ at $30^{\circ} \mathrm{C}$ ), $\mathrm{D}_{2}$ (with $45 \mathrm{pM}\left[{ }^{3} \mathrm{H}\right]$ nemonapride and the same tissue for $90 \mathrm{~min}$ at $30^{\circ} \mathrm{C}$ ), human $\mathrm{D}_{3}$ (with $100 \mathrm{pM}$ $\left[{ }^{3} \mathrm{H}\right]$ nemonapride and recombinant material in cell membranes from cultured genetically transfected mouse fibroblasts at $30^{\circ} \mathrm{C}$ for $60 \mathrm{~min}$ ), and human $\mathrm{D}_{4.2}$ (with $\left.400 \mathrm{pM} \mathrm{[}{ }^{3} \mathrm{H}\right]$ nemonapride with transfected CHO$\mathrm{K} 1$ cells at $20^{\circ} \mathrm{C}$ for $180 \mathrm{~min}$ ). These receptor assays involved triplicate determinations with at least six concentrations of test agents, following initial screening at $10 \mu \mathrm{M}$. Concentration-inhibition functions were computer-fit to determine values of $\mathrm{IC}_{50} \pm \mathrm{SE}$, converted to $\mathrm{Ki}$ from the relationship $\mathrm{Ki}=\mathrm{IC}_{50} /[1+\mathrm{C} / \mathrm{Kd}]$, where $\mathrm{C}$ is the radioligand test concentration, and $\mathrm{Kd}$ is the separately determined affinity of the radioligand. These methods have been reported in detail previously (Kula et al. 1997, 1998).

In addition, DHA-clozapine was evaluated by a commercial screening laboratory (Panlabs/Pharma Services, Ltd., Taipei, Republic of China) for potency in the following radioligand competition assays: $\alpha_{1}$-adrenoceptors (vs. $250 \mathrm{pM}\left[{ }^{3} \mathrm{H}\right]$ prazosin with rat brain homogenates for $30 \mathrm{~min}$ at $25^{\circ} \mathrm{C}$ ), $\alpha_{2}$-adrenoceptors $(700 \mathrm{pM}$ $\left[{ }^{3} \mathrm{H}\right]$ rauwolscine with rat cerebral cortex for $30 \mathrm{~min}$ at $\left.25^{\circ} \mathrm{C}\right), \beta$-adrenoceptors $\left(250 \mathrm{pM}\left[{ }^{3} \mathrm{H}\right]\right.$ dihydroalprenolol with rat brain for $20 \mathrm{~min}$ at $25^{\circ} \mathrm{C}$ ), norepinephrine transporter (200 pM [ ${ }^{125}$ I]RTI-55 with human recombinant material expressed in MDCK cells, for $180 \mathrm{~min}$ at $4^{\circ} \mathrm{C}$ ), dopamine transporter (150 pM [ ${ }^{125}$ I]RTI-55 with human transporter expressed in transfected $\mathrm{CHO}$ cells for 180 $\min$ at $\left.4^{\circ} \mathrm{C}\right)$, serotonin transporter $\left(150 \mathrm{nM}\left[{ }^{125} \mathrm{I}\right] \mathrm{RTI}-55\right.$ with human transporter in HEK-293 cells for $180 \mathrm{~min}$ at $\left.4^{\circ} \mathrm{C}\right)$, the $\mathrm{GABA}_{\mathrm{A}}$ agonist site $\left(1.0 \mathrm{nM}\left[{ }^{3} \mathrm{H}\right]\right.$ muscimol with rat brain for $10 \mathrm{~min}$ at $\left.4^{\circ} \mathrm{C}\right), \mathrm{GABA}_{\mathrm{B}}$ receptor $(10.0$ $n M\left[{ }^{3} \mathrm{H}\right]$ GABA with rat cerebellum for $20 \mathrm{~min}$ at $\left.25^{\circ} \mathrm{C}\right)$, glutamate receptors $\left(1.6 \mathrm{nM}\left[{ }^{3} \mathrm{H}\right] \mathrm{L}\right.$-glutamic acid with rat brain for $10 \mathrm{~min}$ at $37^{\circ} \mathrm{C}$ ), serotonin $5-\mathrm{HT}_{1}$ receptors $\left(2.0 \mathrm{nM}\left[{ }^{3} \mathrm{H}\right] 5-\mathrm{HT}\right.$ with rat cerebral cortex for $10 \mathrm{~min}$ at $\left.37^{\circ} \mathrm{C}\right)$, and $5-\mathrm{HT}_{2}$ receptors $\left(500 \mathrm{pM}\left[{ }^{3} \mathrm{H}\right]\right.$ ketanserin with rat brain for $40 \mathrm{~min}$ at $25^{\circ} \mathrm{C}$ ). 


\section{Tissue Assays of Clozapine}

Aqueous homogenates of brain were extracted into organic solvent, and assayed for clozapine and its major metabolites (norclozapine, and clozapine-N-oxide) as reported and extensively characterized previously (Baldessarini et al. 1993; Volpicelli et al. 1993; Centorrino et al. 1994). Tissue extracts were assayed for clozapine by highly selective, reversed-phase liquid chromatographic separation, and sensitive detection at either $254 \mathrm{~nm}$ or by photodiode-array multi-wavelength (210-340 nm) ultraviolet spectrophotometry, with spectra of peaks in samples compared by microcomputer to those of authentic standards.

For assays of rat brain tissue, ca. $30 \mathrm{mg}$ of striatum was suspended in $1.0 \mathrm{ml}$ of $0.5 \mathrm{M}$ citric acid, sonicated on ice for $5 \mathrm{~min}$, and then centrifuged at 10,000g for $15 \mathrm{~min}$, and held at $-70^{\circ} \mathrm{C}$ until assayed (within two weeks) as with serum samples, adding $300 \mu \mathrm{l}$ of supernatant to $100 \mu \mathrm{l}$ of $5 \mathrm{M}$ aqueous $\mathrm{NaOH}$. Serum $(600 \mu \mathrm{l})$ samples were extracted into ethyl acetate and back into $0.1 \mathrm{~N} \mathrm{HCl}$ to provide $50 \mu \mathrm{l}$ aliquots for assay, at recovery averaging $76 \%$. DHA-clozapine was not recovered through this extraction and separation scheme, but recovery of free clozapine (monitored with triprolidine [Sigma] as an internal standard) was $94 \%$ at $200 \mathrm{ng} / \mathrm{ml}$. Inter-assay coefficients of variation for independently replicated assays of serum and brain samples averaged $2.0 \%$ and $3.2 \%$, respectively. Limits of detection of authentic clozapine were $3.5 \mathrm{ng}$ per $\mathrm{ml}$ (or g) serum or $5.5 \mathrm{ng} / \mathrm{g}$ brain tissue, and about $550 \mathrm{pg}$ per injected sample.

\section{RESULTS}

\section{Preliminary Assessment of Novel Agents}

The novel fatty-acid amide derivatives of clozapine (Table 1) were evaluated initially for acute effects on spon- taneous locomotor activity at $10-70$ min after i.p. injection, as well as for ability to inhibit locomotor behavioral arousal induced by apomorphine $(1 \mathrm{mg} / \mathrm{kg}$, i.p.) injected at $6 \mathrm{~h}$ after the test agents. All fatty acid derivatives showed significant early reduction of spontaneous locomotor activity at $1 \mathrm{~h}$, ranging from $48 \%$ reductions for linoleoylclozapine and oleoylclozapine, $52-53 \%$ reductions with the myristoyl and palmitoyl derivatives, $70 \%$ reduction by free clozapine, and an $85 \%$ effect with DHA-clozapine (data not shown). However, by $6 \mathrm{~h}$ after injection, only DHA-clozapine showed significant, dose-dependent (1-10 mg/ $\mathrm{kg}$, i.p.) reductions of both spontaneous and apomorphinestimulated locomotor activity.

Based on these observations, several doses of DHA itself were given in control experiments, but the free fatty acid (1-30 $\mathrm{mg} / \mathrm{kg}$, i.p.) had no significant behavioral depressant effect on spontaneous locomotion or against arousal induced by apomorphine at 1-2 hours (not shown), nor against apomorphine at 6-7 hours (Table 2). All of the novel test agents were also compared with treatment with free clozapine. Representative results with high doses of all compounds tested are shown (Table 2). Based on these preliminary results, the DHA-clozapine derivative was selected for further testing.

\section{Affinities at Dopamine Receptors and Other Potential Drug Target Sites}

Comparisons of clozapine with DHA-clozapine and free clozapine in assays of all four major types of dopamine receptors indicated that clozapine had moderate affinity $(\mathrm{Ki}=132-158 \mathrm{nM})$ at receptors $\mathrm{D}_{1}, \mathrm{D}_{2}$, and $\mathrm{D}_{3}$, and somewhat higher affinity at $\mathrm{D}_{4}$ receptors in transfected cell lines $(\mathrm{Ki}=43.6 \mathrm{nM})$, consistent with expectations. However, DHA-clozapine and DHA itself showed no detectable potency in any dopamine recep-

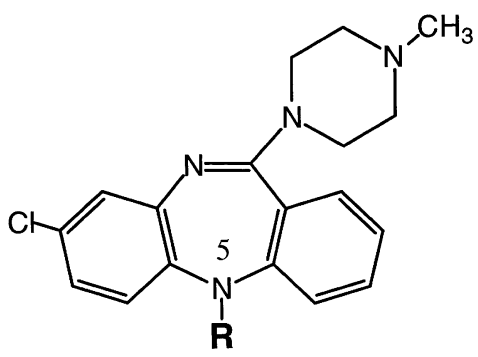

Table 1. Fatty-Acid Amide Derivatives of Clozapine

\begin{tabular}{lll}
\hline Compound & \multicolumn{1}{c}{ Substituent (R) } & MW \\
\hline Clozapine & $-\mathrm{H}$ & 326.8 \\
N-Myristoylclozapine & $-\mathrm{CO}\left(\mathrm{CH}_{2}\right)_{12} \mathrm{CH}_{3}$ & 537.2 \\
N-Palmitoylclozapine & $-\mathrm{CO}\left(\mathrm{CH}_{2}\right)_{14} \mathrm{CH}_{3}$ & 565.2 \\
N-Linoleoylclozapine & $-\mathrm{CO}\left(\mathrm{CH}_{2}\right)_{7} \mathrm{CH}=\mathrm{CHCH}_{2} \mathrm{CH}=\mathrm{CH}_{2}\left(\mathrm{CH}_{2}\right)_{4} \mathrm{CH}_{3}$ & 589.3 \\
N-Oleoylclozapine & $-\mathrm{CO}\left(\mathrm{CH}_{2}\right)_{7} \mathrm{CH}=\mathrm{CH}\left(\mathrm{CH}_{2}\right)_{7} \mathrm{CH}_{3}$ & 591.3 \\
N-Docosahexaenoylclozapine & & \\
\end{tabular}

${ }^{a}$ DHA-clozapine. Compounds in ascending order of molecular weight (MW). 
Table 2. Effects of Clozapine and Fatty-Acid Derivatives Against Apomorphine at Six Hours After Administration

\begin{tabular}{lcc}
\hline Treatment & $\begin{array}{c}\text { Locomotor } \\
\text { Activity } \pm \text { SEM }\end{array}$ & $\begin{array}{c}\text { \% of Apomorphine } \\
\text { Response }\end{array}$ \\
\hline Vehicle control & $878 \pm 130$ & $10.6 \pm 1.6$ \\
Apomorphine alone & $8,294 \pm 698$ & $100.0 \pm 8.4$ \\
Oleoylclozapine & $7,545 \pm 490$ & $90.0 \pm 5.9$ \\
Linolenoylclozapine & $7,416 \pm 598$ & $89.4 \pm 7.2$ \\
Myristoylclozapine & $7,121 \pm 648$ & $85.8 \pm 7.8$ \\
DHA alone & $6,793 \pm 781$ & $81.9 \pm 8.4$ \\
Palmitoylclozapine & $5,940 \pm 1130$ & $71.6 \pm 13.6$ \\
Clozapine & $5,855 \pm 412$ & $70.6 \pm 5.0^{a}$ \\
DHA-clozapine & $445 \pm 32.3$ & $5.37 \pm 0.39^{a}$ \\
\hline
\end{tabular}

Results for clozapine, its derivatives, and DHA at $10 \mathrm{mg} / \mathrm{kg}$, i.p. (other doses, 1, 3, $5 \mathrm{mg} / \mathrm{kg}$, not shown).

${ }^{a}$ Treatment with DHA-clozapine and, weakly, clozapine were significantly and dose-dependently active in reducing acute apomorphine (1 $\mathrm{mg} / \mathrm{kg}$, i.p.) induced locomotor activity at 6-7 $\mathrm{h}$ after injection of test drugs, based on 1-way ANOVA for dose (F[4; $25 \mathrm{df}] \geqslant 5.34$, for overall $p \leqslant$ $0.03)$, and post-hoc Scheffé tests ( $p<.05$ for dose shown). Agents ranked in ascending order of apparent efficacy as apomorphine antagonists.

tor assay, except for a weak interaction of DHA-clozapine at $\mathrm{D}_{1}$ sites $(\mathrm{Ki}=800 \mathrm{nM})$ in rat forebrain (Table 3 ). Moreover, broader screening of DHA-clozapine for activity in radioligand competition assays for other potential drug target sites also failed to show substantial potency (all $\mathrm{Ki}=10,000 \mathrm{nM}$ ) at any site considered, including adrenergic, serotonin, GABA, and glutamate receptors, and monoamine transporters, indicating that DHA-clozapine, in contrast to free clozapine, showed little or no evidence of direct neuropharmacological activity.

\section{Comparison of Duration and Potency of DHA-Clozapine and Clozapine}

Representative doses of clozapine and DHA-clozapine were further tested for ability to inhibit behavioral arousal induced by a standard dose of apomorphine (1 $\mathrm{mg} / \mathrm{kg}$, i.p.) given just prior to recording locomotor activity, at various times post-injection of the test agents

Table 3. Dopamine Receptor Affinities of Docosahexaenoic Acid, DHA-Clozapine and Clozapine

\begin{tabular}{lccc}
\hline Receptor & DHA & $\begin{array}{c}\text { Ki }(\boldsymbol{n M}) \text { by Agents } \\
\text { DHA-Clozapine }\end{array}$ & Clozapine \\
\hline $\mathrm{D}_{1}$ & $>10,000$ & $800 \pm 90$ & $132 \pm 10$ \\
$\mathrm{D}_{2}$ & $>10,000$ & $>10,000$ & $154 \pm 55$ \\
$\mathrm{D}_{3}$ & $>10,000$ & $>10,000$ & $158 \pm 35$ \\
$\mathrm{D}_{4}$ & $>10,000$ & $>10,000$ & $43.6 \pm 8.5$ \\
\hline
\end{tabular}

Data derived from radioreceptor affinity assays described in Methods, shown as $\mathrm{Ki}(\mathrm{nM}) \pm \mathrm{SE}$ values determined by computed data-fits. $\mathrm{D}_{1}$ and $\mathrm{D}_{2}$ assays vs. $\left[{ }^{3} \mathrm{H}\right] \mathrm{SCH}-23390$ or $\left[{ }^{3} \mathrm{H}\right]$ nemonapride with rat striatal membrane-containing homogenates; other assays used $\left[{ }^{3} \mathrm{H}\right]$ nemonapride with cell membranes from transfected mouse fibroblasts $\left(\mathrm{D}_{3}\right)$ or $\mathrm{CHO}-\mathrm{K} 1$ cells $\left(D_{4.2}\right)$ expressing human receptor genes.
(Figure 1). Both agents produced dose-dependent inhibition of apomorphine-induced arousal. However, at doses of $1 \mathrm{mg} / \mathrm{kg}$ and $3 \mathrm{mg} / \mathrm{kg}$, the DHA derivative was more potent initially, even though its molar doses were $51 \%$ of those of free clozapine. Moreover, the behaviorally inhibitory effects of DHA-clozapine were much more prolonged than those of free clozapine. For example after $10 \mathrm{mg} / \mathrm{kg}$ doses, the effects of clozapine were largely dissipating by $4-8 \mathrm{~h}$ post-injection, whereas DHA-clozapine continued to antagonize acute challenges with apomorphine for at least $24 \mathrm{~h}$, when arousal was still decreased by $36 \%$ by the fatty-acid derivative (Figure 1).

Similarly prolonged anti-apomorphine effects of DHA-clozapine $(10 \mathrm{mg} / \mathrm{kg}$ or $15.7 \mu \mathrm{mol} / \mathrm{kg})$ were found after oral (p.o.) administration as well as systemic injections (i.p.) - again, much longer than with a twice-larger molar dose of clozapine $(10 \mathrm{mg} / \mathrm{kg}$ or 30.6 $\mu \mathrm{mol} / \mathrm{kg}$ ). The behavioral effects of DHA-clozapine following oral administration remained within $20-30 \%$ of those found after injection, indicating substantial oral bioavailability for this compound (Figure 2).

Doses of DHA-clozapine and clozapine were compared by behavioral testing for $1 \mathrm{~h}$ after administering apomorphine $(1 \mathrm{mg} / \mathrm{kg}$, i.p.) at $3 \mathrm{~h}$ after the test agents were injected at doses of $1-30 \mathrm{mg} / \mathrm{kg}$, i.p. (Figure 3). DHA-clozapine inhibited apomorphine-induced behavioral arousal by $50 \%$ at a dose of about $3.2 \mathrm{mg} / \mathrm{kg}$, i.p., whereas free clozapine required a dose of about 17 $\mathrm{mg} / \mathrm{kg}$. The computed molar-equivalent, half-maximally effective doses $\left(E_{50} \pm \mathrm{SE}\right)$ for DHA-clozapine vs. clozapine were $5.0 \pm 0.7$ vs. $52.0 \pm 11.6 \mu \mathrm{mol} / \mathrm{kg}$, indicating that the DHA-derivative was over 10-times more potent on a molar-equivalent basis (Figure 3).

\section{Catalepsy Ratings}

Rats (4/group) were tested for catalepsy for $60 \mathrm{~min}$ after injections of the following test agents in doses of (10 $\mathrm{mg} / \mathrm{kg}$, i.p.): clozapine, DHA-clozapine, DHA, as well as the standard test vehicle (not shown). The control vehicle injections produced a mean \pm SEM score of $2.00 \pm$ 0.41 units. Clozapine produced a somewhat higher mean score of $7.50 \pm 2.25(p=.05)$, than an approximately equimolar dose of DHA-clozapine $(20 \mathrm{mg} / \mathrm{kg})$ at $6.00 \pm 1.08$, and DHA $(10 \mathrm{mg} / \mathrm{kg}$, at a score of $2.50 \pm$ $0.29)$ was indistinguishable from vehicle controls.

When DHA-clozapine was given at the same dose as that of clozapine, its cataleptic effect was even weaker, at $2.75 \pm 0.48$ units, and not significantly different from the vehicle controls. By comparison, we found in separate experiments that haloperidol (RBI) produced a mean score of $180 \pm 40$ units at a computed dose of 0.25 $\mathrm{mg} / \mathrm{kg}$, indicating that clozapine and DHA-clozapine had very little cataleptic activity. 

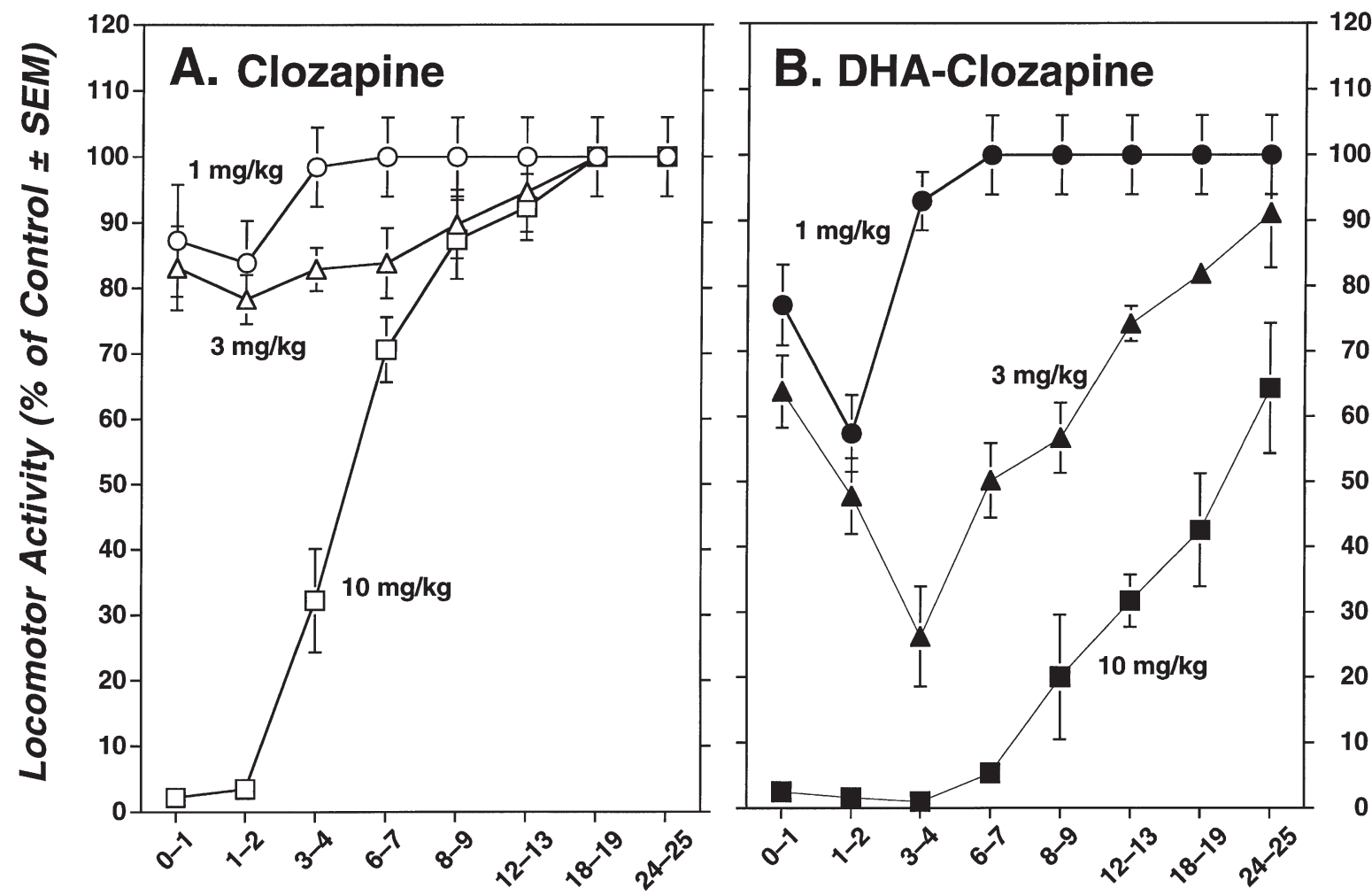

Apomorphine Testing Time (hours post-treatment)

Figure 1. Mean \pm SEM percentage of locomotor activity for $n=6$ fresh rats per group, induced by challenge doses of apomorphine $(1 \mathrm{mg} / \mathrm{kg}$, i.p.) given at indicated times following treatment with a range of doses of clozapine or DHA-clozapine (1-10 mg/kg, i.p.). Control values $(100 \%)$ are for apomorphine following vehicle injections at the stated times.

\section{Tissue Concentrations of Clozapine}

Assays of serum and brain concentrations of clozapine (found in brain and serum) and its metabolites (norclozapine and clozapine-N-oxide, found only in serum) were done at $45 \mathrm{~min}$ or $8 \mathrm{~h}$ after a large dose of clozapine $(20 \mathrm{mg} / \mathrm{kg}$, i.p.) or an equimolar dose of DHAclozapine $(61.2 \mu \mathrm{mol} / \mathrm{kg})$. Tissue analyte concentrations obtained at $45 \mathrm{~min}$ following injection of clozapine were very similar to previously reported findings with rat tissue (Baldessarini et al. 1993). In contrast, DHAclozapine yielded very low levels of clozapine or its metabolites in serum at 45 min after injection, and undetectable levels at $8 \mathrm{~h}$ (Figure 4 ). In the brain, levels of free clozapine were much lower after treatment with DHA-clozapine than after clozapine (1075 vs. $550 \mathrm{ng} / \mathrm{g}$ ) at $45 \mathrm{~min}$, and were lower but still detectable (ca. 100 $\mathrm{ng} / \mathrm{g}$ ) at $8 \mathrm{~h}$ after giving both agents (Figure 4). Giving DHA-clozapine not only greatly limited serum levels of free clozapine at both sampling times, but also yielded relatively lower brain levels than were found following injections of clozapine. The ratio of brain:serum concentrations of clozapine was much greater following DHAclozapine, or approximately two at $45 \mathrm{~min}$ following a large dose of clozapine (ca. 1,200/600 ng/g), but $>20$ following an equimolar dose of DHA-clozapine (ca. 570 vs. $25 \mathrm{ng} / \mathrm{g}$ ). These findings are consistent with the view that DHA-clozapine favored delivery of clozapine away from blood to brain in comparison to treating with free clozapine itself.

\section{DISCUSSION}

The present findings indicate that fatty acid amide derivatives of clozapine can be produced and that at least one of these, DHA-clozapine, shows several pharmacologically interesting characteristics. These include central depressant and anti-apomorphine activity in the rat following oral administration as well as systemic injection, resembling the actions of free clozapine itself, while lacking evidence of direct neuropharmacological activity at dopamine receptors or other potential drug target sites, in contrast to free clozapine. In addition, DHA-clozapine proved to be more than 10-times more potent than clozapine (Figure 3), and much longer-acting, with substantial anti-apomorphine effects found at 


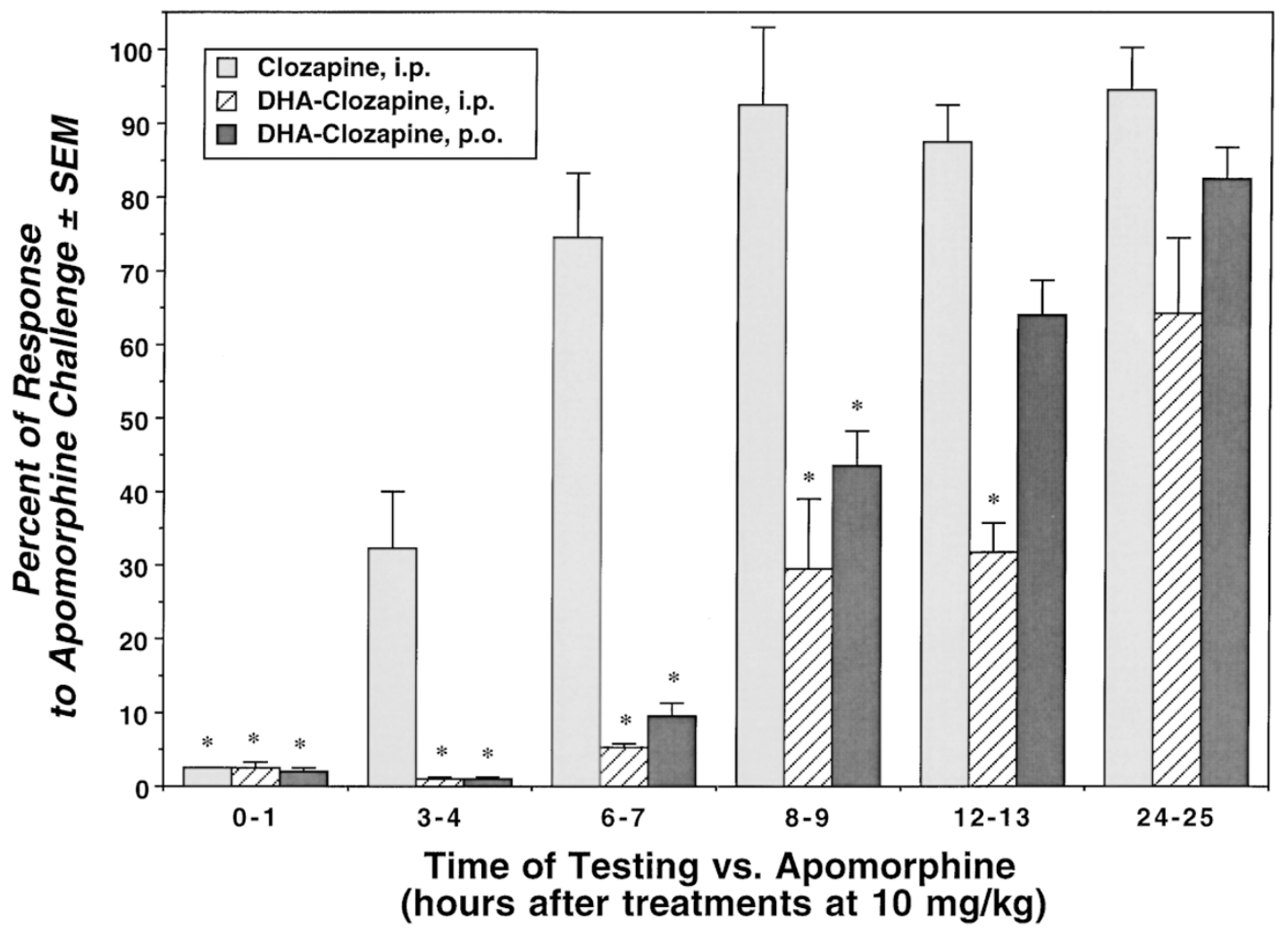

Figure 2. Mean \pm SEM percentage of locomotor activity for $n=6$ fresh rats per group, induced by challenge doses of apomorphine (1 mg/kg, i.p.) given at indicated times following treatment with a dose of clozapine (10 mg/kg, i.p. [open bars]), DHA-clozapine (10 mg/kg, i.p. [striped bars], or p.o. [dark bars]). Control values (100\%) are for apomorphine following vehicle injections at the stated times. * indicates statistically significant differences from controls $(p<.05)$ based on 2 -way ANOVA (for treatment and time), with post-hoc testing for planned comparisons.

$24 \mathrm{~h}$ after administration of $10 \mathrm{mg} / \mathrm{kg}$, either intraperitoneally or orally (Figure 2). Moreover, DHA-clozapine produced even weaker cataleptic effects than clozapine, which has very limited extrapyramidal activity, suggesting that it, too, may prove to be an atypical antipsychotic agent with improved pharmacological properties.

In addition, administration of a large dose of DHAclozapine led to very low circulating concentrations of clozapine and its principal metabolites at $45 \mathrm{~min}$, and undetectable levels at $8 \mathrm{~h}$. In contrast, injections of clozapine itself produced high serum concentrations of clozapine analytes at $45 \mathrm{~min}$, and detectable serum levels were found $8 \mathrm{~h}$ later (Figure 4). Some clozapine was detected in brain at both $45 \mathrm{~min}$ after an injection of DHA-clozapine, but these concentrations were lower than were produced by clozapine itself. At $8 \mathrm{~h}$, similar low concentrations of free clozapine were detected in brain after treatment with clozapine or DHA-clozapine (Figure 4), at a late time when the behavioral effects of clozapine had virtually disappeared, but DHA-clozapine was still very active (Figures 1 and 2).

These findings based on tissue assays of clozapine and its metabolites are consistent with the hypothesis that administration of DHA-clozapine might limit peripheral tissue-exposure to potentially toxic free clozapine and its metabolites, while enhancing central clozapine-like neuropsychopharmacological activity. This limitation of exposure to clozapine is particularly significant from the perspective of total exposure of peripheral tissues to free clozapine over the 24-h active time-course of action of DHA-clozapine. If access of clozapine to peripheral sites is important in mediating its systemic adverse effects, this effect may be clinically useful.

The low concentrations of clozapine detected in brain tissue following administration of DHA-clozapine almost certainly represent free clozapine and not the clozapine moiety in DHA-clozapine since DHAclozapine does not extract or co-elute with clozapine under the reported assay conditions (Flood JG 1999, unpublished observations). The presence of free clozapine in brain may mediate the antidopaminergic behavioral effects reported. It is also possible that free clozapine in brain tissue may contribute to risk of centrally mediated adverse effects including excessive sedation or seizures. However, since seizure-risk is reportedly dosedependent (Welch et al. 1994), the slow delivery of 


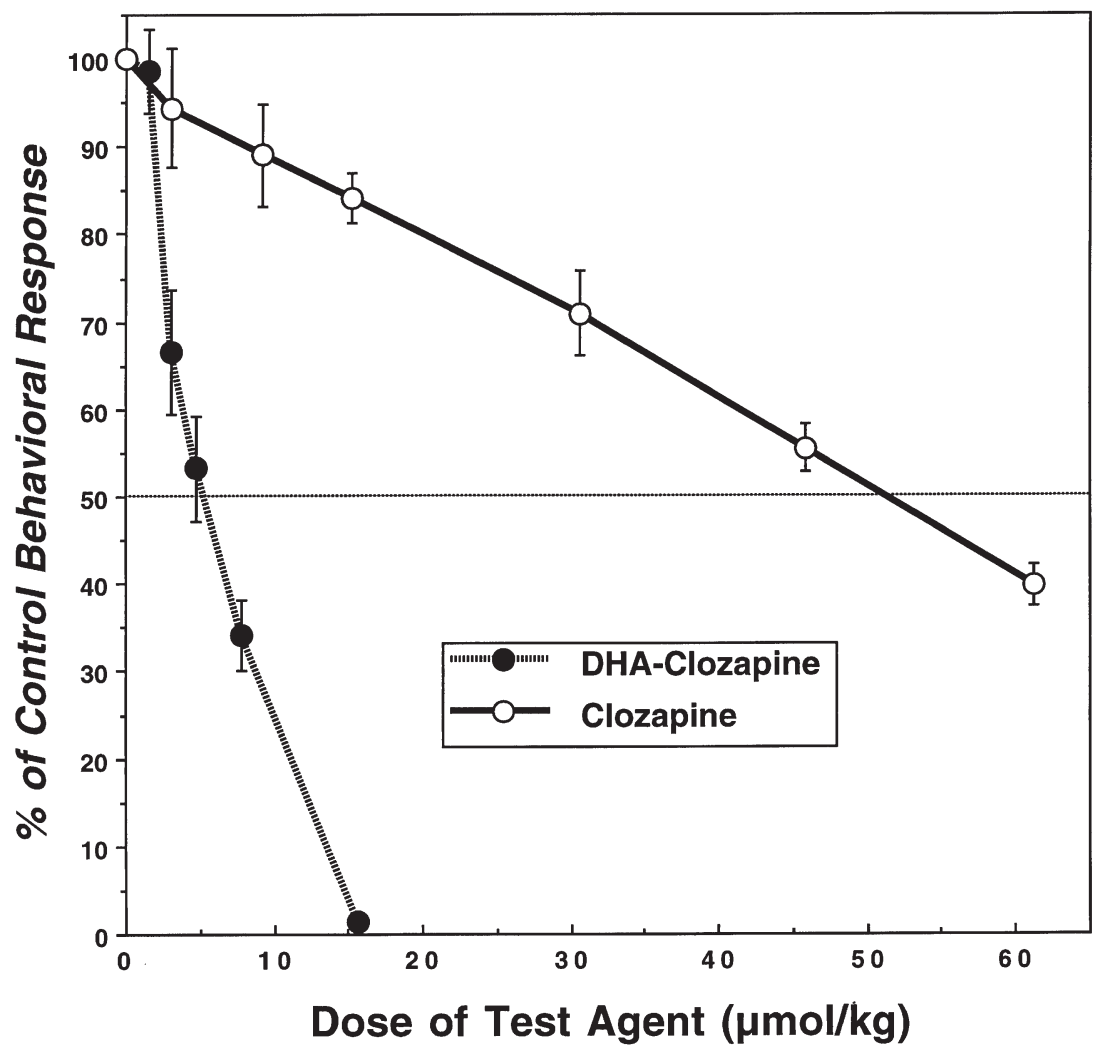

Figure 3. Dose-response comparisons for clozapine (open circles) and DHA-clozapine (filled circles), based on inhibition of locomotor arousal induced by apomorphine challenges $(1 \mathrm{mg} / \mathrm{kg}$, i.p.) at $6-7 \mathrm{~h}$ after initial treatment with a range of indicated comparable molar doses of test agents $(\mu \mathrm{mol} / \mathrm{kg}$, i.p.). Data are mean \pm SEM percentage of control locomotor activity for $n=6$ fresh rats per group. Dotted horizontal line indicates $50 \%$ inhibition $\left(\right.$ at $\left.\mathrm{ED}_{50}\right)$. lower levels of clozapine to brain over the 24-h cycle than were found after giving clozapine (Figure 4) may limit seizure risk as well as risk of peripheral toxicity associated with high tissue burdens of free clozapine and its metabolites. Adequate assessment of these predictions will require further direct experimental testing in human subjects.

The lack of evidence of direct neuropharmacological activity of DHA-clozapine in assays of representative receptor and other potential drug target sites, coupled with the presence of detectable levels of free clozapine in brain tissue appear to be consistent with the hypothesis that DHA-clozapine may not be active itself but, instead, a vector and precursor of free clozapine as an active metabolic product, possibly by the action of ubiquitous tissue peptidases. It is also possible that amide substitution at the normally accessible 5-nitrogen of clozapine prevents or delays its oxidative inactivation to clozapine-N-oxide (Baldessarini and Frankenburg 1991; Jann et al. 1993), further contributing to prolonged pharmacological activity.

A related question is whether the prolonged, potent behavioral actions of DHA-clozapine may reflect effects of the fatty acid moiety DHA, rather than the clozapine component of the amide derivative. This question is particularly timely in view of recent evidence that longchain unsaturated fatty acids in certain natural-product seed or fish oils that include DHA may have antimanic or antidepressant effects in patients with bipolar disorder, perhaps including those refractory to standard treatments (Stoll et al. 1999). However, control experiments using injections of DHA alone in the present study found no evidence of behavioral depressant effects, nor of significant potency at dopamine receptors (Tables 2 and 3).

A major question arising from the present observations is how to account for the special properties of DHA-clozapine not found with other long-chain, unsaturated (linoleic, oleic) or saturated fatty acids (myristic, palmitic). The brain is highly dependent on external supplies of fatty acids, which readily pass through the blood-brain barrier (Spector 1988). It is not clear that DHA reaches the brain by mechanisms not shared with other unsaturated fatty acids. However, there is evidence that saturated and unsaturated fatty acids may enter by dissimilar mechanisms. Saturated fatty acids, especially those with relatively short carbon-chains, enter by a probenecid-sensitive, low-affinity, high-capacity transport process that may involve protein receptor or carrier molecules, whereas entry of unsaturated fatty acids occurs through a less well understood process that is not inhibited by probenecid (Spector 1988; Avellini et al. 1994). Further complication is introduced by the uncertain role of circulating albumin and proteolipids as avid carriers of fatty acids that reach the brain, possibly through the mediation of low-density proteo- 


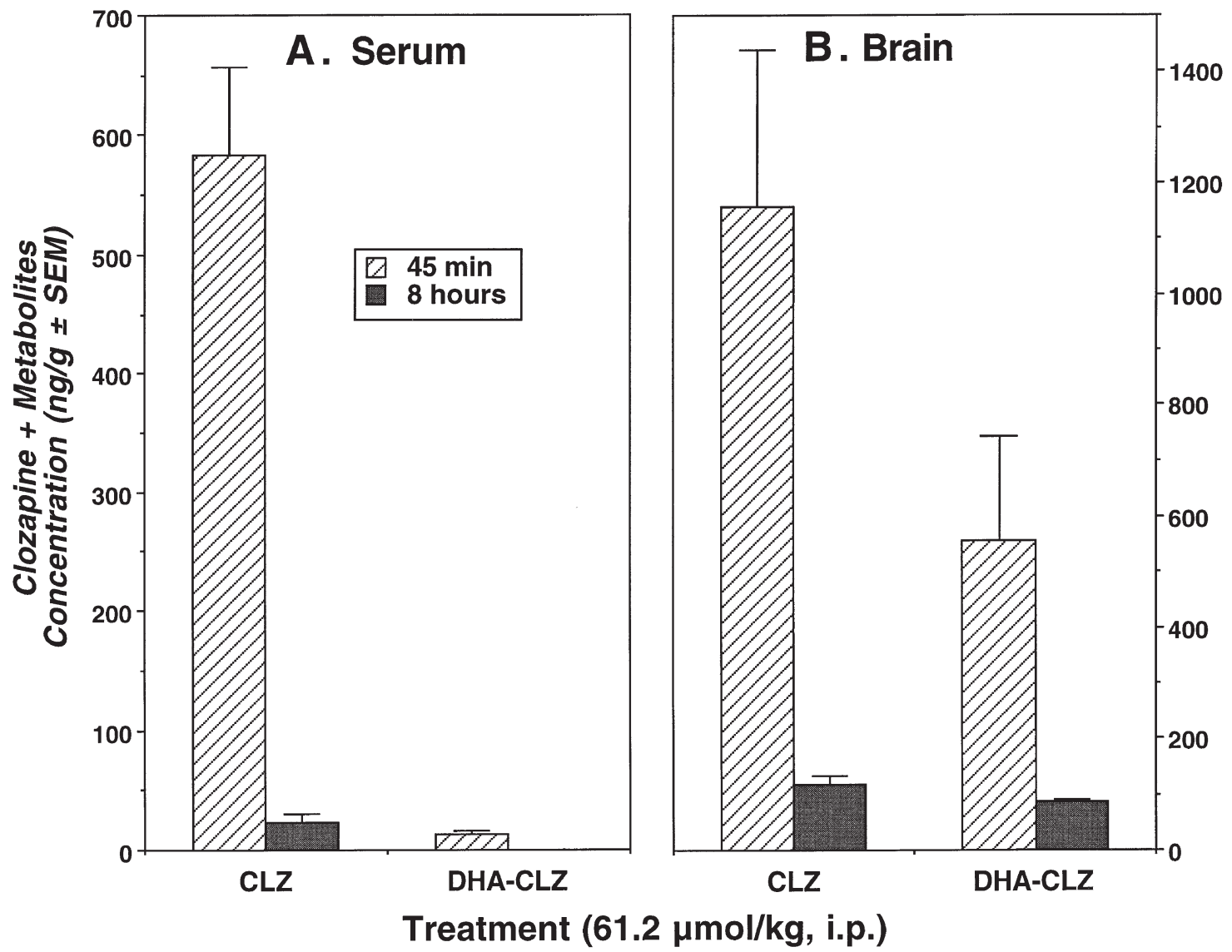

Figure 4. Mean \pm SEM serum concentrations of clozapine and metabolites in serum (A) and whole brain tissue (B) from $n=6$ rats per condition, at 45 min (striped bars) and $8 \mathrm{~h}$ (dark bars) after injections of large, equimolar doses of clozapine and DHA-clozapine $(61.2 \mu \mathrm{mol} / \mathrm{kg}$, i.p.).

lipid receptor proteins at the blood-brain barrier (Spector 1988; Avellini et al. 1994; Dehouck et al. 1997). The tendency for fatty acids to attach to proteins may also contribute to the prolonged actions of DHA-clozapine. Although a full explanation of the unique properties of the DHA derivative of clozapine found in the present study is not available, it is important to emphasize that the fatty acid amides of clozapine are significantly modified molecules, including occlusion of their usually free carboxylic groups, so that their tissue disposition and brain entry may not necessarily parallel that of the free fatty acids from which they were prepared.

To recapitulate, among amide derivatives of clozapine linked to a series of long-chain, unsaturated or saturated fatty acids that are important components of cerebral lipids, only the DHA-derivative, $\mathrm{N}$-docosahexaenoylclozapine (but not the clozapine-5-N-amides of linoleic, myristic, oleic, or palmitic acids) had potent and long-acting central depressant and anti-apomorphine (antidopaminergic) activity in rat. DHA itself was inactive up to very high doses $(30 \mathrm{mg} / \mathrm{kg}$, i.p.). DHAclozapine was orally bioavailable and more than 10- times more potent $\left(\mathrm{ED}_{50}=5.0 \mu \mathrm{mol} / \mathrm{kg}\right)$ than clozapine itself. It was also very long-acting against behavioral arousal induced by acute challenge doses of apomorphine, for at least $24 \mathrm{~h}$ after a single i.p. dose of DHAclozapine at $10 \mathrm{mg} / \mathrm{kg}(16 \mu \mathrm{mol} / \mathrm{kg})$, including rats exposed to apomorphine only once. DHA-clozapine produced even less catalepsy than clozapine, suggesting limited extrapyramidal effects. After systemic administration of DHA-clozapine, brain concentrations of free clozapine were much greater than corresponding serum levels, but lower than after injecting clozapine. Taken together, the thrust of the available evidence is that DHA-clozapine is not likely to be directly neuropharmacologically active as an intact molecule, and more likely to serve as a delivery molecule to provide free clozapine selectively to cerebral tissues over prolonged times after systemic or oral administration.

In conclusion, DHA-clozapine is a unique neuropsychopharmacologically active, orally bioavailable and long-acting agent with potent and prolonged antidopaminergic activity after systemic administration, associated with markedly reduced peripheral exposure to 
free clozapine over time, but with delivery of free clozapine to brain over times as long as 24 hours. DHA-clozapine was virtually inactive in direct assays of affinity at all dopamine receptor types as well as to a number of other potential drug target sites. Given these pharmacological properties, DHA-clozapine or similar agents should be evaluated as potential antipsychotic drugs with improved central/peripheral distribution, and possibly enhanced safety that requires verification in clinical trials. Moreover, the principle represented in linking a known centrally active drug with a fatty acid carrier molecule such as DHA as a means of enhancing CNS distribution and activity may be applicable to other compounds of neuropsychopharmacological interest, including hydrophilic agents that poorly penetrate the blood-brain barrier (Jacob et al. 1985; Shashoua and Hesse 1996).

\section{ACKNOWLEDGMENTS}

Supported, in part, by NIMH grants MH-34006, MH-47370, the Bruce J. Anderson Foundation, the McLean Hospital Private Donors' Neuropharmacology Research Fund, and a research award from Protarga, Inc.

\section{REFERENCES}

Alvir JMJ, Jeffrey PH, Lieberman JA, Safferman AZ, Schwimmer JL, Schaaf JA (1993): Clozapine-induced agranulocytosis: Incidence and risk factors in the US. N Engl J Med 329:162-167

Avellini L, Terracina L, Gaiti A (1994): Linoleic acid passage through the blood-brain barrier and a possible effect of age. Neurochem Res 19:129-133

Baldessarini RJ, Frankenburg FR (1991): Clozapine-a novel antipsychotic agent. New Engl J Med 24:746-754

Baldessarini RJ, Centorrino F, Flood JG, Volpicelli SA, Huston-Lyons D, Cohen BM (1993): Tissue concentrations of clozapine and its metabolites in the rat. Neuropsychopharmacology 9:117-124

Baldessarini RJ, Jamison KR (1999): Effects of medical interventions on suicidal behavior: Summary and conclusions. J Clin Psychiatry 60 (Suppl 2):117-122

Bazan NG (1990): Supply of n-3 polyunsaturated fatty acids and their significance in the central nervous system. In Wurtman RJ, Wurtman JJ (eds), Nutrition and the Brain, Vol 8. New York, Raven Press, pp 1-24

Bazan NG, Birkle D, Reddy TS (1985): Biochemical and nutritional aspects of the metabolism of polyunsaturated fatty acids and phospholipids in experimental models of retinal degenerations. In LaVail MM, Anderson M, Hollyfield J (eds), Retinal Degeneration: Experimental and Clinical Studies. New York, AR Liss, pp 159-187

Bondolfi G, Dufour H, Patris M, May JP, Billeter U, Eap CB, Baumann P (1998): Risperidone vs clozapine in treat- ment-resistant chronic schizophrenia: A randomized double-blind trial. Am J Psychiatry 155:499-504

Campbell A, Baldessarini RJ, Cremens MC (1988): Dose-catalepsy response to haloperidol in rat: Effects of gender and strain. Neuropharmacology 11:1197-1199

Campbell A, Baldessarini RJ, Cremens C, Teicher MH, Marsh ER (1989): Bromocriptine antagonizes behavioral effects of cocaine in the rat. Neuropsychopharmacology 2:209-224

Campbell A, Baldessarini RJ, Gao Y, Ram VJ, Neumeyer JL (1990): R(-) and S(+) stereoisomers of 11-hydroxy- and 11-methoxy-N-n-propylnoraporphine: Central dopaminergic behavioral activity in the rat. Neuropharmacology 29:527-536

Campbell A, Baldessarini, RJ, Neumeyer JL (1993): Altered spontaneous behavior and sensitivity to apomorphine in rats following pretreatment with $\mathrm{S}(+)$-aporphines or fluphenazine. Psychopharmacology 111:351-358

Campbell A, Villavicencio AT, Yeghiayan SK, Balikian R, Baldessarini RJ (1997): Mapping of locomotor behavioral arousal induced by microinjections of dopamine within nucleus accumbens septi of the rat forebrain. Brain Res 771:55-62

Centorrino F, Baldessarini RJ, Kando J, Frankenburg FR, Volpicelli SA, Puopolo PR, Flood JG (1994): Serum concentrations of clozapine and its major metabolites: Effects of cotreatment with clozapine and fluoxetine or valproate. Am J Psychiatry 151:123-125

Dehouck B, Fenart L, Dehouck M-P, Pierce A, Torpier G (1997): A new function for the LDL receptors: Transcytosis of LDL across the blood-brain barrier. J Cell Biol 138:877-889

Gerlach J (1991): New antipsychotics: Classification, efficacy and adverse effects. Schizophrenia Bull 17:289-309

Hägg S, Joelsson L, Mjorndal T, Spigset O, Oja G, Dahlqvist R (1998): Prevalence of diabetes and impaired glucose tolerance in patients treated with clozapine compared with patients treated with conventional depot neuroleptic medications. J Clin Psychiatry 59:294-299

Innis SM (1991): Essential fatty acids in growth and development. Prog Lipid Res 30:39-103

Jacob JN, Shashoua VE, Campbell A, Baldessarini RJ (1985): Synthesis, brain uptake and pharmacological properties of lipid esters of $\gamma$-aminobutyric acid. J Med Chem 28:106-110

Jann MW, Grimsley SR, Gray EC, Chang W (1993): Pharmacokinetics and pharmacodynamics of clozapine. Clin Pharmacokinet 24:161-176

Kane JM, Honigfeld G, Singer J, Meltzer HY, Clozaril Collaborative Study Group (1988): Clozapine for the treatment resistant schizophrenic: A double-blind comparison with chlorpromazine. Arch Gen Psychiatry 45:789-796

Kula NS, Baldessarini RJ, Kebabian JW, Bakthavachalam V, Xu L (1997): RBI-257, a highly potent dopamine $\mathrm{D}_{4}$ receptor-selective ligand. Eur J Pharmacol 331:333-336

Kula NS, Tarazi FI, Baldessarini RJ, Xu L, Bakthavachalam V, Pounds S, True CD (1998): Neuropharmacological assessment of potential dopamine $\mathrm{D}_{4}$ receptor-selective ratioligands. Eur J Pharmacol 367:139-142 
Lieberman JA, Safferman AZ, Pollack S, Szymanski S, Johns C, Howard A, Kronig M, Bookstein P, Kane JM (1994): Clinical effects of clozapine in chronic schizophrenia: Response to treatment and predictors of outcome. Am J Psychiatry 151:1744-1752

Martin RE, Bazan NG (1992): Changing fatty acid content of growth cone lipids prior to synaptogenesis. J Neurochem 59:318-325

Martin RE, Rodriguez de Turco EB, Bazan NG (1994): Developmental maturation of hepatic n-3 polyunsaturated fatty acid metabolism: Supply of docosahexaenoic acid to retina and brain. J Nutr Biochem 5:151-160

Meltzer HY (1998): Suicide in schizophrenia: Risk factors and clozapine treatment. J Clin Psychiatry 59(Suppl 3):15-20

Scott BL, Bazan NG (1989): Membrane docosahexaenoate is supplied to the developing brain and liver by the liver. Proc Natl Acad Sci U S A 86:2903-2907

Shashoua VE, Hesse GW (1996): N-docosahexaenoyl-3hydroxytyramine: A dopaminergic compound that penetrates the blood-brain barrier and suppresses appetite. Life Sci 58:1347-1357
Söderberg M, Edlund C, Kristensson K, Dallner G (1991): Fatty acid composition of brain phospholipids in aging and in Alzheimer's disease. Lipids 26:421-425

Spector R (1988): Fatty acid transport through the bloodbrain barrier. J Neurochem 50:639-643

Stoll AL, Severus WE, Freeman MP, Rueter S, Zboyan HA, Diamond E, Cress KK, Marangell LB (1999): Omega-3 fatty acids in bipolar disorder. Arch Gen Psychiatry 56:407-412

Volpicelli S, Centorrino F, Puopolo P, Kando J, Frankenburg FR, Baldessarini RJ, Flood JG (1993): Determination of clozapine, norclozapine and clozapine-N-oxide in serum by liquid chromatography. Clin Chem 39:16561659

Wahlbeck K, Cheine M, Essali A, Adams C (1999): Evidence of clozapine's effectiveness in schizophrenia: A systematic review and meta-analysis of randomized trials. Am J Psychiatry 156:990-999

Welch J, Manschreck T, Redmond D (1994): Clozapineinduced seizures and EEG changes. J Neuropsychiatry Clin Neurosci 6:250-256 